\title{
AIDS activists says basic research is underfunded
}

Washington. Despite extra resources from the US government to combat AIDS, research is skewed against critical basic work on the pathogenesis of the disease and leading researchers are "chronically demoralized", according to a new report by an influential AIDS activist group.

The Treatment Action Group (TAG) emboldened by its success last year in framing recommendations which Congress last month incorporated into reform of the $\mathrm{Na}$ tional Institutes of Health (NIH)'s Office of AIDS Research - plans a year-long campaign for greater support of such work as well as other aspects of its report, to be published next week at the Ninth International Conference on AIDS in Berlin. The report, based on interviews with 36 AIDS investigators in the United States, also calls for a further shift in research away from testtube work towards investigations that deal with patients.

TAG would like NIH to move substantially away from in vitro work and towards in vivo research exploring the behaviour of HIV (human immunodeficiency virus) in the human body. "AIDS research came of age at the same time as molecular biology, in the late 1980s" says the report's author, Gregg Gonsalves of TAG. "As a result, people moved away from looking at the patient."

Recent work such as that by NIH's Anthony Fauci on the lymph node (Nature 362, 355 ; 1993) reflects a welcome shift back towards the study of the pathogenesis of the disease in the body, TAG says. The work should be extended to ways in which the human immune system controls the virus, to find out, for example, why some people with high CD4 counts contract AIDS while others register low counts but show no symptoms, and why those directly exposed to HIV manage to resist infection.

Gonsalves estimates that NIH receives two to three times more top-quality grant applications for basic work on AIDS than it can fund. Although he concedes that a similar situation exists in most fields, he would like work on AIDS pathogenesis to be made an exception because "it is our number one public health problem".

TAG argues that the best way to find a cure for AIDS is to put more of the $\$ 1.3$ billion that the US government spends on AIDS into investigator-initiated individual grants known as R01 awards. "We don't need a Manhattan project for AIDS", says Gonsalves. "The best thing to do is to increase the size of the R01 pool." He argues that the ability of large research centres to marshal support for large clinical trials, for example, has given them an unfair advantage over individual researchers desperate for funds.

"We were disturbed to see the level of morale in the research community", Gonsalves says. "Funding is very tight, and there is chronic demoralization among the researchers."

Colin Macilwain

\section{Australian state wants claim to native plants}

Sydney. The government of the Australian state of Queensland is expected some time this year to declare its right to a share of any financial gain made from research involving native plants and animals.

The legislation, which has yet to be written or submitted to the Queensland Parliament, will state that the government is entitled to part of the money from the sale of compounds or genes derived from native plants and animals. It is believed to be the first attempt by any government to assert a blanket legal claim to the commercial rights resulting from such research.

Although the policy, to be attached to the existing Nature Conservation Act, may well have little effect outside Australia, or even outside the state, its purpose is to reinforce the state's international rights to naturally occurring compounds and genes under the Biodiversity Convention. That convention was signed in June 1992 and is intended to balance the rights of developing nations with the commercial practices of the industrial world. Although the federal government is responsible for international matters, states are free to make laws on matters such as logging in forests and mineral exploitation.

Gordon Guymer, head of the Queensland Herbarium (a Queensland government department) and a proponent of state claims to its natural resources, points out that a compound found in the seeds of the native tree, the Morton Bay Chestnut, which has shown promise as an anti-cancer agent, has recently been patented by a Japanese company. A better-known example is the discovery that the bark of the Pacific yew tree, native to Queensland as well as to other parts of the world, contains taxol, a substance effective against ovarian cancer.

An official in the office of the chief scientist for the federal government says that he is puzzled by the proposed legislation. Although it is possible to patent genetically altered animals, he says, it is another matter to declare one's rights to natural life forms.

\section{Rumoured good news raises share price of vaccine company}

Washington. Shares in the US biotechnology company Immune Response Corporation have doubled in value over the past few weeks in anticipation of the results of therapeutic AIDS vaccine trials to be announced next week at the international AIDS conference in Berlin.

But as interest in the stock has soared in one day last week its price gained $\$ 4$, to $\$ 22$, and one-sixteenth of its shares changed hands - some AIDS researchers were critical of the publicity surrounding the release of the closely guarded results and accused the company, which is based in San Diego, California, of trying to put pressure on the US Food and Drug Administration (FDA) to approve its vaccine.

The vaccine used in the trials was developed by Jonas Salk, a co-founder and director of the company and chairman of its scientific advisory board. Salk, who holds 1 per cent of the company's 16.5 million shares, is a champion of 'killed-virus' vaccines of the type that he invented to treat polio before a successful alternative was devised by Albert Sabin.

But some AIDS researchers who doubt the value of therapeutic vaccines in general, and a killed-virus vaccine in particular, are worried that the significance of the trial results will be exaggerated by thousands of reporters in Berlin looking for miracle-cure stories. Salk's vaccine excludes gp120, the basis of other therapeutic vaccines under development. "I'm sceptical about therapeutic vaccines - the jury is still out on their potential", says Paul Maddon, chief executive officer of the New York biotechnology company Progenics Pharmaceuticals Inc., which is developing diagnostics, therapeutic treatments and preventative vaccines for HIV.

Salk declined to comment on the significance of the results of the trials, which will be announced on 9 June by the company's chief scientist, Dennis Carlo. The results involve a five-year follow-up to a study of 23 patients, as well as preliminary data from a one-year trial of 103 patients.

The FDA has been reluctant to license killed-virus vaccines because of the possibility of the accidental infection of patients if the vaccine is mishandled. But market analysts speculate that the company could file an application for the vaccine within months.

Anthony Fauci, director of the National Institutes of Allergy and Infectious Diseases and of NIH's Office of AIDS Research, declined to comment specifically on the Salk vaccine. But he pointed out that "the history of the international AIDS conference is that things do get blown out of proportion".

Colin Macilwain 